\title{
The Impact of using "Active Learning" At the Achievement of the Sixth Primary Grade Female Students in Geometry
}

\author{
Abed El-Kareem M. Farajallah, PhD. \\ Assistant professor of curriculum and math, Al Aqsa \\ University-Gaza \\ Palestine, Gaza Strip, Nussirat \\ Al Aqsa University-Gaza
}

\author{
Salem E. Al arjani \\ BA, MPH, MOH, PNA \\ Palestine, Gaza Strip, Rafah \\ Al Quds Open University -Middle area
}

\begin{abstract}
This study aims at investigating the impact of using "Active Learning" at the achievement of the sixth primary grade female students in Geometry. The researchers have adopted the experimental research approach to achieve this goal. The study sample consists of (108) female students divided into two groups , (control and experimental); the experimental group, which consists of (54) female students was taught by using the active learning method, while the other group, the control, that contains the same number of the earlier was taught by using traditional teaching methods. An achievement test was applied on both groups and the study has reached a set of results; of the most important: There were a significant differences between control and experimental groups in favor of the experimental group, in addition to a statistically significance differentials between the rises and falls of achievement of the control and experimental groups in favor of the rises and falls of achievement of the experimental group.
\end{abstract}

\section{General Terms}

Mathematics teaching, geometry

\section{Keywords}

Active learning, Traditional learning, Mathmatics

\section{INTRODUCTION}

The teaching-learning process has been ongoing since the dawn of history. However, at the modern age, Education was taken new trends that is moving rapidly and inspiring its tendency by the modern discoveries proposed by the scientific and experimental researches in the field of Psychology and Education, and that emphasis the importance of learner and taking care of his inclinations and interests. The teaching methods in modern education are varied according to the change of perception towards the nature of the education process which has been widened to cover the higher-level cognitive instead of depending on memorizing and recitations, requires the positivity of the student in learning.

Mathematics has received a great share of attention for it overlaps with all life activities of the learner as it aims at presenting and Promoting the students' full capacity, which motivate them to carry out a renewable types of innovative activities that shows all their cognitive and creative capabilities and so it develops their abilities towards free creative thinking and enable them to unleash their intellectual abilities.
The things that distinguish Mathematics curriculums is that it focuses upon Geometry as an essential component of these curriculums which make Mathematics becomes more meaningful, understandable, and clear; as long as students are acquainted, through their activities, with the concepts of Geometry and what they mean. Hence, the trend towards a qualitative shift was emerged in teaching and learning of Mathematics in order to furnish students with Geometry and to apply it properly through the most educational methods novelty which is, the so-called, Experiment-Based Learning or Active Learning ( Saada and others, 57:2006).

Active learning considers as one of the most modern educational methods, for it's the one that gives students the opportunities of participation, interacting, and working within Mathematics, where pupils are active and energetic, and they can build, instruct, or adjust ideas and Mathematical concepts by interacting with their surroundings (Abu Zienah and Ababneh, 2007 : 25).

It is a learning method that allows the student to participate effectively into class activities, as the events of active learning includes a variety of learning techniques such as using small groups, playing various roles, making diverse projects, and asking multi-level questions so that the first and the basic objective of these activities is to encourage students into selfeducate under the supervision of their teacher (poppenhagen,2006,19).

Active learning is a teaching method that depends on selfactivity and positive participation of the learner, in which he searches using a range of activities and scientific processes under the supervision and guidance of the teacher. Evidence indicates that active learning helps students enjoy learning and gives them the ability to acquire skills and knowledge which turns the educational processes between teacher and student into an interesting partnership (Bedier,2008,35).

And so, the learning process is the student's responsibility which will help him exert more effort and the optimal investment of his mental abilities and take advantage of the supporting educational environment of active learning, which links the student with the subject he's learning. Active learning provides students with the motives to learn Mathematics and its concepts through offering challenging issues for it's a source of scientific joy for students. In addition to its capability to develop positive attitudes towards Mathematics through raising students' interest to learn math. On the contrary, the lack of using the active learning methods in teaching mathematics in our schools is one of many causes for students to hate Mathematics (Bedier,2008,38) . Teachers 
today offer Mathematics to students inappropriately that doesn't raise their ideas nor encourage them to think in order to gain educational outcomes in a new innovative of their own which obscures them lots of opportunities for diligence, originality, and creativity.

Geometry has an important role in student's learning, and the development of their ability in order to face problems and life situations, as active learning basically depends on the positivity and interaction of students, it gives them the opportunity to make an effort in order to learn about Geometry through interaction, work, and various activities through observation, conclusion, and search for information on their own under the supervision and guidance of the teacher.

Based on the above, the issue of study came up and which lies in the difficulty of understanding Geometry, therefore it's an urgent need to conduct the current research which tries to overcome the difficulties facing students in their Geometry learning, through using active learning which provides flexible learning environment that works to reflect the Geometry through investing the capabilities and capacities of students, the thing that make it easier to learn, understand, and embrace. Therefore the current study tries to answer the following primary question:

\subsection{Research Problem}

tries to answer the following primary question

"What is the Impact of Using Active Learning at the Achievement of Sixth primary grade Students in Geometry?"

Through the key question above, the following sub-questions are derived:

1. Does the achievement level of the six primary grade female students in Geometry differs in the two groups (control and experimental) according to the method of teaching (traditional /active learning)?

2. Does the achievement level of the six primary grade female students in Geometry changes the achievement rises in the two groups (control and experimental) according to the method of teaching (traditional /active learning)?

3. Does the achievement level of the six primary grade female students in Geometry changes the achievement ' in the two groups (control and experimental) according to the method of teaching (traditional /active learning)?

\subsection{Assumptions of the Study}

Along with the research problem, the researchers sought to investigate the accuracy of the following assumptions:

1. There are no statistically significant differences at the significance level $(\alpha \leq 0.05)$ between the grades' average of the six primary grade female students in Geometry of the experimental group, and the grads' average of the control group in the post achievement test.

2. There are no statistically significant differences at the significance level $(\alpha \leq 0.05)$ between the grades' average of high achievement female students in the six primary grade female students at the experimental group, and the grades' average of low achievement female students at the control group in the post achievement test.

3. There are no statistically significant differences at the significance level $(\alpha \leq 0.05)$ between the grades average of low achievement female students in the six primary grade female students at the experimental group, and the grades' average of low achievement female students at the control group in the post achievement test.

\subsection{Study Objectives}

The study seeks to achieve the following primary objective: To identifying the impact of using active learning at the achievement of the six primary grade female students in Geometry.

\subsection{Importance of the Study}

1. The study benefits at urging teachers on using active learning for the achievement of the subject's objectives in an interesting way.

2. The study considered as the first to use active learning in Palestine.

3. It benefits the teachers of Mathematics to facilitate some lessons that considered hard for the students to learn.

4. It may contribute with the refinement of the six primary grade female students' achievement level.

5. It may contribute in attracting the organizers of training courses' attention to include "using active learning in training teachers in-service" in their training-ships.

6. This thesis leads the Educational Supervisors to adopt the teaching method by using active learning.

\subsection{Study limitation}

The study limitations confined to the following:

- Objectives limit: the study confined to determine the impact of using active learning at the achievement of six primary grade female students in Geometry.

- Institutional limit: UNRWA schools.

- $\quad$ Location limit: the study was applied on the six primary grade female students at Nuseirat " $F$ " elementary school.

- $\quad$ Time limit: the study was applied in the second semester of the academic year 2011-2012.

\subsection{Procedural Definitions of the Study Procedural Definitions:}

The procedural definitions include the basic terms as follows:

Active learning: is the learning where the student practice variety of activities, and which provide her with the opportunity to learn Geometry through the work and the activity in an interesting education environment that encourages her to use learning resources and grab the tangible mathematical tools, and the positive participation of learning activities with a high level of freedom, privacy, responsibility, and control to formulate mental experience that includes cognitive reconstruction of the students. 


\section{THEORETICAL FRAMEWORK 2.1 The Concept of Active learning}

The concept of active learning had been defined with too many definitions by the specialist and the scholars of Education. However Contradicted these definitions may be in the way it deals with the concept of active learning, but the common factor among all of these definitions is the emphasis upon the importance of such type of learning on the teachinglearning process. From among these definitions are the following:

- A method of teaching and learning at the same time in which the students involves with various activities that permit them on the positive listening, conscious thinking, and the proper analysis of the subject, where the students share ideas with the present of the teacher which leads them toward the achievement of learning objectives. (Saada and others , 33:2006)

- Educational philosophy depends on the positivity of the learner in the Educational situation. It includes a number of Pedagogical practices and teaching procedures that lead into activating the role of learner, where learning is being done through work, research, and experimentation. Thus, the learner reaches the information by depending on himself. The same thing is in acquiring skills and formatting trends and values, as he focuses on developing thinking and capacity to solve problems and group or cooperative work ( Al-Astal, 81:2010).

- $\quad$ According to Matthews(2:2006), active learning is a method through which the student indulges with the varies classroom activities instead of being a negative individual who just receive information from the others, therefore active learning encourages the students' participation in the interacting through the work within groups.

Active learning is the one where the learners participate actively in the learning process through reading and research and the participation in classroom or non-classroom activities, where the learner is being as mentor and supervisor of to the learning process. (Al-Legany and Jamal 254:2003).

Through the foregoing we can say that: Active learning is the type of learning that stands for the varies activities that a learner practice, and results in behaviors depends on the active and positive participation of the learner in the Educational situation considering the leaner as the core of the learning process.

\subsection{Objectives of Active Learning}

The objectives of active learning are represented by the following (Saada and others, 2006), ( Zaidi,2008) (Maliky,2009)

1. Encouraging students on acquiring the skills of critical thinking an reading.

2. Verifying the suitable learning activities to achieve the desired learning objectives.

3. Supporting the students' self-confidence towards the varies fields of knowledge, and assisting them to discover the important issues.

4. Encouraging students to ask different questions.
5. Measuring students' ability to form and organize new ideas.

6. Empowering students to acquire the skills of cooperating, interacting, and contacting with others.

7. Increasing the students' creative works.

8. The students' acquirement of the desired skills, trends, and knowledge.

9. Encouraging students to acquire higher-order thinking skills like analysis, synthesis, and evaluation.

10. Increasing learners ability on grasping knowledge, forming meaning for it, and receiving it.

11. Encouraging students to participate in set the objectives of their learning and seek towards achieving them with taking the responsibility for their learning.

12. Facilitate learning through the learners' attainment to practical experiences that is connected with real problems

\subsection{The importance of active learning}

Active learning has a great importance, and its usage has a great value. In this concept Educators should encourage using active learning for its capability to enable the learners to express about what they learn, therefore they could write about it, connect and apply it in their daily life as it contributes in learners' learning for concepts and information which attract their interest, and remembering the information they understand (Astal 15:2010)

Active learning increases the percent of students' ability in keeping knowledge, increases the interaction inside the class, develop students'

positive trends towards the educational subject, and towards themselves, colleagues, and teachers. In addition, active learning develops the various thinking skills, focuses upon students' achievement and support trust between teachers and learners. Learning daily skills also could be another gaining from active learning (Abdul-Karim 86:2009).

The importance of active learning appears through the positive results that affects the learner's knowledge, skills and trends. And which was confirmed and supported by the educational researches about active learning.

Through active learning, the students learn the concepts and the information that tract their interest and remember the information that they understand then they apply the knowledge through what they learn, also the students express about what they learn, therefore they could write about it, connect it with their own experience and apply it in their daily life to make what they have learned a part of their own self and their being (Maddah 43:2009).

\subsection{The role of teachers in Active Learning}

Although the learner in active learning bears the brunt in the process of his educating, but the role of teacher considers to be very important represented by: considering individual differences among students; considering the values, trends, interests, and inclinations of the students; assisting students to discover information and knowledge on their own; considering the integration the different subjects; acquiring students the different skills; involving all students in learning 
activities; and asking questions that encourage thinking, meditation, and using knowledge. (Astal, 17:2010)

\subsection{The role of learner in Active learning}

The roles of learner in active learning are represented through: the real participation in the educational experiences, estimating the value of exchanging ideas with others, exerting the required effort and allocating enough time for organized meetings with the school counselor, and his understanding that his development as individual starts first from himself. Thus he accepts the advice and suggestions from teachers and educators.

Also, among his roles, his own seeking for information among the different sources, his participation to evaluate himself, identifying the objectives he had achieved, and participating with his friends in group work as he initiates to ask questions or comment on what have been said or raised of issues or new ideas (Maliki 67:2009).

Therefore the role of learner is being changed from negative. inert element into the important element which make the learning process attractive to the student and makes him a participant in drawing training and learning programs.

\subsection{Strategies of active learning}

Active learning strategies considers as a reflection for the ideas advocated by the Constructivist theory and which emphasis the importance of learners' constructing to their own information through their interacting with their nature. Among the strategies of active learning is the following: small and large groups, cooperative learning, experience-based learning, providing learning, direct learning, independent learning, modified lecture, role modeling, brain storming, story, simulation, case study, discussion and dialogue, role playing, asking questions.

When implementing the strategies of active learning it must consider listening to learners, encouraging open discussion, accepting learners' ideas, allowing time to think, providing easy feed-back, establishing trust relations between learner and teacher, developing the faith in learners through the discussion in the ideas they supply (Zaidi, 65:2008)

\subsection{Principles of Active Learning}

There are some principles that should be taken into consideration when implying active learning in the classroom. Among which that active learning benefits at (Saada and others, 2006) (Bedier, 2008) (Astal, 2010) :

1. encouraging the interaction between teacher and learner inside and outside the classroom through motivating and participating learners.

2. Encouraging cooperation among learners, as a good teaching is the one that raises cooperation and sharing among its members.

3. Encouraging students to learn better through writing and speaking about what they learn and connecting it with their past experience, then applying it in their daily life.

4. Providing quick feedback, because the learners need to meditate about what they learn.

5. The necessity of providing enough time for learning, because learners need to master the skill of time management.
6. Setting high expectations for the students performance and working on achieving it.

7. The right teaching practices are the ones that take into consideration the variety of learners' intelligence and the variety of teaching methods.

8. Connecting active learning situations with the students' previous knowledge .

9. Providing the element of choice and challenge and focusing upon social interaction, dialogue, and adopting the various points of view.

10. Depending on cooperation, negotiation, and meditating as an important basis of active learning.

Therefore, we find that active learning is one of the contemporary patterns of education that has its own modern teaching methods and techniques and which consider the learner is the center of the educational process as it is an education based upon the various activities that the practiced by the learner and which results in some behaviors depended on the learner's active positive participation in educational situation.

\section{PREVIOUS STUDIES}

The researchers had reviewed various studies that were concerned in study's variable. In the next paragraph we will explore some studies that are deucedly ordered according to the application or publication date:

Maddah (2009) did a study aimed to attract the effect of Using "active learning" at the achievement of some geometrical concepts. and the students' trends in fifth grade in Makka city towards Mathematics. The study used a Quasi - Experimental Method and the sample consisted of (68) female students in the fifth grade in Makka city from two different schools, two classes was randomly chosen. One of the two groups represent the (34) female students experimental group subjected to active learning, and the other (34) female student control group were subjected to regular learning. The study tools consisted of testing the geometrical concepts and the measurement their trend towards Mathematics, and a group of active learning activities. The study found that there were a significant differences in testing geometrical concepts and the scale of trend towards Mathematics in favor of the experimental group in the post application.

Fox's study (Fox, 2008) also sought to discover the effectiveness in the use of calculators provided with graphics in active learning's environment on students' achievements in Algebra and their attitudes towards it, it is an experimental study combined of (166) students divided into six classes distributed in two groups; the first, the experimental, used calculators provided with graphics in an environment of active learning, and the second, the control, used regular calculators, and study tools were represented in an achievement test, and a measure of the trend towards Mathematics, and results indicated the effectiveness of active learning in the academic success, and there's an increase by $15 \%$ in the number of students who were able to success in Intermediate Algebra in the classes of active learning.

The study of Suliman (2004) used active learning in teaching counting in order to notice its impact on the achievement of middle school students, and develop their counting sense. The study sample consisted of (195) of 2nd secondary students from the provinces of Al-Moutawafia and Al-Gharbia, divided into 2 experimental groups and a control group, and the 
results showed statistically significant differences between these groups in favor of the two experimental groups which studied by means of active learning.

And the study of Abu Al-Hamad (2004) aimed to identify the effectiveness of using two strategies on the achievements of Fourth grades in Mathematics and their readiness to study it, it's an experimental study consisted of (103) students of Fourth grade in the province of Al- Mania , in which they were divided into 3 groups; control group (37) students, experimental group \#1 (34) students, and experimental group \#2 (32), and study tools were represented in an achievement test, and the scale of tendency towards mathematics, papers, and teacher's guide according to strategic, and results showed the prevalence, in achievement and Inclination, of the two experimental groups at the expense of the control group. The experimental group was also prevalent in the trend towards Mathematics however without the achievement.

On the same level, the study of David and Wilder (David \& Wilder, 2003) proved that using active learning in teaching Mathematics allows the development of concepts and helps learners to intake abstractions and to create perceptions helps them to think about what they're doing, which gives them the ability of understanding concepts and enables them to grasp the concepts and all the topic's points with accurate conscious comprehension which assists them on the process of guessing, persuading, appreciation, observation, understanding peculiarities and generalities, and building knowledge by themselves.

AL- toudry conducted (2003) a study aimed to investigate the effect of a proposed study to teach mathematics. ( the strategy of active learning ) on the achievement of the third elementary class their preserve of learning and their capacity of translating verbal exercises. The study also aimed at investigating the effect of the strategy at the development of mathematical thinking for students. The study sample consisted of (84) male and female students of the third elementary class in Assiut province. The students were divided into two equally groups; on experimental and the other control. Three tests were applied on them: the first was an achievement test in Mathematics for the third elementary class, post applied and delayed. The second was a test in translating verbal exercises, post applied. The third test was in Mathematical thinking, pre and post applied. The study found statically significance differences in the post implementation for each of the three tests in favor of the experimental test.

While the study done by Asser (2001) aimed at investigating the efficiency of the active learning that depends on the handmade items in teaching equations Algebraic inequalities for the students of first intermediate in Al-Quseem. The experimental approach was applied in this study, and the study population consisted of all students in Al-Quseem schools which their sum is (8043) student, and the study sample consisted of (60) students. The tools of the study were: an achievement test and the scale of trend towards Mathematics. The study resulted in: the existence of statistical significant differentials in the achievement of Mathematics in favor of the experimental group, and the existence of statically significant differentials in the trend towards Mathematics in favor of the experimental group.

Coy investigated (2001) the effect of using problem solving as a techniques for active learning to develop the skills of problem solving in adding, subtracting, dividing multiples of decimal fractions. The study sample consisted of the fifth grade elementary students at Western Betera schools, and the students had been divided into two groups; an experimental group which studied by using problem solving as one of active learning techniques, and a control group studied by using traditional method. The study used an achievement test in problem solving and was applied on the two groups before and after the experiment. At the end the study reached that there are statically significant differences between the two groups in the skills of solving problems in favor of the students of the experimental group.

\section{STUDY FIELD PROCEDURES}

First/Study Approach: the experimental approach, which is based on the design of two random (experimental and random) groups, was executed by using the experimental design of the pre and post tests for two equivalent groups .

Second/ The Study Population: it consists of all the sixth primary grade female students in Al-Wostah province-Gaza. Which consist of (2904) students in the second semester of the academic year 2011-2012 according to the census of UNRWA.

\section{Third / The Study Sample:}

The study sample consisted of two academic divisions where randomly chosen from among all the divisions in the Nuseirat "F" elementary school. One division, consisted of (46) students, was assigned as an experimental group. The other division, consisted of (47) students, was assigned as a control group.

\section{Fourth / Study Tools:}

\subsection{Content analysis tool}

The researchers analyzed the content of the fifth unit entitled by (Geometry and measurement) of the Mathematic text book for the sixth primary grade female students using analysis tool. The construction of this tool went through the following procedures:

\subsubsection{Identifying the objective of analysis process:}

Content analysis process aims at categorizing the content into three cognitive levels which are: conceptual knowledge, procedural knowledge, solving the course problems, degree of redundancy, presentation style, and preparing a list of these problems.

\subsubsection{Identifying the study sample:}

The analysis sample included the content of the fifth unit entitled by (Geometry and measurement) of the Mathematic text book for the sixth primary grade female students.

\subsubsection{Identifying analysis categories:}

The analysis category included a list of the following three cognitive levels: the conceptual knowledge, the procedural knowledge, and solving problems.

\subsubsection{Identifying unit analysis:}

The basic idea around which the content of presented ideas organized such as the unit of content analysis, and then formulating the basic idea in a form of behavioral objective.

\subsubsection{Regulations of analysis process:}

The analysis is being done in the content framework which includes the purport of ideas' presentation. 
The analysis is being done here in the light of conceptual knowledge, procedural knowledge and problem solving where the following procedural definitions are being adopted:

- Conceptual knowledge: includes the re-organization of the relations between facts, information, and assumptions related to the concept of a single network, and presenting it in a Mathematical form.

- Procedurals Knowledge: includes the identification of Algorisms and the skill of executing procedures and rules of solution.

- Problem solving: includes the non-routinely verbal matters and which contains an abstract in the way of its solution or includes the implementation of knowledge in a new situations.

- A table is being used to record the results and recurrence each of: conceptual knowledge, procedural knowledge and problems solving.

\subsubsection{Analysis accuracy:}

The accuracy of analysis process was confirmed through representing the analysis tool on a committee of arbitrators specialist in; Education, curriculums, and teaching methods in the Palestinian Universities. Who display their agreement with the analysis process.

\subsubsection{Analysis reliability:}

in order to judge the reliability of the analysis process, the researchers had re-analyzed the content of the fifth unit entitled by (Geometry and measurement) of the Mathematic text book for the sixth primary grade female students after (21) days of the first analysis. Next, the reliability coefficient was calculated and it was (96\%), in addition to another content analysis by another analyst and calculating reliability coefficient with Holsti's equation (97\%).

\subsection{Achievement test}

In order to identify the impact of active learning at the achievement of the sixth primary grade female students in Geometry, an achievement test was prepared to attain that purpose. To reach with the achievement test for the final formulation it had to go through the following steps:

\subsection{1 identifying the objective of selection:}

The achievement test aims at measuring the effect of active learning at the achievement of the sixth primary grade female students in Geometry.

\subsubsection{Identifying the subject's content:}

The content fifth unit entitled by "Geometry and Measurement" in the Mathematics book for the sixth primary grade students was analyzed.

\subsubsection{Identifying the educational objectives:}

That includes identifying the measurable objectives that the student must reach after studying the textbook in its procedural figure. The objectives had been formed and determined in the light of the textbook units.

\subsubsection{Categorizing Educational objectives:}

Educational objectives had been categories into its three cognitive levels, which are: (conceptual knowledge level, procedural knowledge level, and problem solving) Next, a number of questions were identified for each lesson according to the objectives.

\subsubsection{Preparing standards' table:}

A test standards' table had been prepared, which is explained by the following table.

Table No.(4.1) explains the relative weights for the topics of "teaching principles and skills" course

\begin{tabular}{|l|c|c|c|c|c|c|c|c|}
\hline & \multicolumn{7}{|c|}{ Objective level } & \multicolumn{2}{l|}{} \\
\hline Unit title & \multicolumn{2}{|l|}{$\begin{array}{l}\text { Problem } \\
\text { solving }\end{array}$} & \multicolumn{2}{l|}{$\begin{array}{l}\text { Procedural } \\
\text { knowledge }\end{array}$} & $\begin{array}{l}\text { Conceptual } \\
\text { knowledge }\end{array}$ & \multicolumn{2}{l|}{ Sum } \\
\hline $\begin{array}{l}\text { Geometry } \\
\text { and } \\
\text { measurement }\end{array}$ & $\mathbf{A v}$. & No. & Av. & $\mathbf{. 0 N}$ & Av. & oN. & Av. & oN. \\
\cline { 2 - 9 } & $24.5 \%$ & 17 & $45 \%$ & 18 & $12.5 \%$ & 5 & $100 \%$ & 40 \\
\hline
\end{tabular}

\subsubsection{Formulating the test's concepts:}

It was formulated as multiple-choice.

\subsection{7 setting the instructions of the \\ achievement test:}

the instructions includes the following:

1. Examined subjects information.

2. Instructions specific to the test's description. Which are the number of paragraphs, the number of alternatives, the number of pages.

3. Instructions specific to the answer about all questions by putting a circle around the correct answer.

\subsubsection{The primary form of the achievement}

test:

the test, in its primary form, consisted of (44) types of multiple choice clauses and arithmetic questions. After the writing the test's paragraphs, it was presented in front of a committee of judges specialists in education, curriculums, and teaching methods at the Palestinian universities to execute the operations of adding, editing, or deleting in some paragraphs according to their suggestions to be the final form of the test consisting of (40) paragraphs.

\subsubsection{Exploratory experimentation of the achievement test:}

after preparing the test in its primary form, the test was applied on exploratory sample consists of (42) female student of the sixth primary grade outside the study sample. the exploratory experiment was executed in order to: calculate the ease and discrimination factors of the test's paragraphs, calculate the accuracy and reliability of the test, and identifying the time he takes to answer the test when implementing it on the primary study sample.

\subsubsection{0 correcting the achievement test:}

the test had been corrected after the answer of the exploratory sample students on the test's paragraphs. Where one mark was identified for each paragraph of the multiple choice. Thus, the grade that a student can get confined between (zero and 40 marks). 


\subsubsection{1 identifying the time of the achievement} test:

it was found that the right time to imply this test is (120) minutes, as it was calculated through the following equation:

test's time $=($ the time the first student will take + the time that the last student will take) / 2 .

\subsubsection{2 analyzing the achievement test's} paragraphs:

the students' grades were analyzed in order to identify: the degree of ease and discrimination factor for each paragraph of the test, and so it was as explained in the following table:

table (2) explains the degree of ease and discrimination factor for each paragraph of the achievement test used to measure the impact of using active learning at the achievement of the sixth primary grade students in Geometry.

\subsubsection{3 the accuracy and reliability of the} achievement test:

the accuracy of the achievement test was confirmed through:

$$
\text { accuracy of arbitrators: }
$$

The achievement test was presented in front of a group of arbitrators specialized in education, curriculums, and teaching methods at the Palestinian universities in order to be channeled by their points of view about the suitability of the test's paragraphs to their objectives. Also to ensure the validity of wording and clarity. Based on the arbitrators suggestions; adding, editing, and deleting some paragraphs of the test had been done.

$$
\text { accuracy of internal consistency: }
$$

The accuracy of internal consistency was confirmed by calculating Pearson's correlation coefficient between the marks of each paragraph of the test and the final mark of the achievement test. That was through applying the achievement test on an exploratory sample consisted of (42) female students from outside the study sample. As it's explained in table (4-2).
Table (4-2) presents the correlation coefficient of each paragraph of the test and the final mark of the achievement test *

\begin{tabular}{|l|l|l|l|l|l|l|l|l|}
\hline $\begin{array}{l}\text { I.N } \\
\text { o. }\end{array}$ & $\begin{array}{l}\text { Corr. } \\
\text { Co. }\end{array}$ & $\begin{array}{l}\text { Sig } \\
\text { lev } \\
\text { el }\end{array}$ & $\begin{array}{l}\text { I.N } \\
\text { o. }\end{array}$ & $\begin{array}{l}\text { Corr. } \\
\text { Co. }\end{array}$ & $\begin{array}{l}\text { Sig } \\
\text { lev } \\
\text { el }\end{array}$ & $\begin{array}{l}\text { I.N } \\
\text { o. }\end{array}$ & $\begin{array}{l}\text { Corr. } \\
\text { Co. }\end{array}$ & $\begin{array}{l}\text { Sig } \\
\text { lev } \\
\text { el }\end{array}$ \\
\hline 1 & 0.727 & $* *$ & 15 & 0.573 & $* *$ & 29 & 0.738 & $* *$ \\
\hline 2 & 0.464 & $* *$ & 16 & 0.640 & $* *$ & 30 & 0.550 & $* *$ \\
\hline 3 & 0.738 & $* *$ & 17 & 0.501 & $* *$ & 31 & 0.564 & $* *$ \\
\hline 4 & 0.384 & $*$ & 18 & 0.449 & $* *$ & 32 & 0.471 & $* *$ \\
\hline 5 & 0.371 & $*$ & 19 & 0.550 & $* *$ & 33 & 0.553 & $* *$ \\
\hline 6 & 0.536 & $* *$ & 20 & 0.396 & $* *$ & 34 & 0.550 & $* *$ \\
\hline 7 & 0.515 & $* *$ & 21 & 0.727 & $* *$ & 35 & 0.639 & $* *$ \\
\hline 8 & 0.441 & $* *$ & 22 & 0.389 & $* *$ & 36 & 0.738 & $* *$ \\
\hline 9 & 0.684 & $* *$ & 23 & 0.484 & $* *$ & 37 & 0.727 & $* *$ \\
\hline 10 & 0.554 & $* *$ & 24 & 0.545 & $* *$ & 38 & 0.487 & $* *$ \\
\hline 11 & 0.608 & $* *$ & 25 & 0.559 & $* *$ & 39 & 0.564 & $* *$ \\
\hline 12 & 0.384 & $*$ & 26 & 0.727 & $* *$ & 40 & 0.592 & $* *$ \\
\hline 13 & 0.738 & $* *$ & 27 & 0.536 & $* *$ & & & \\
\hline 14 & 0.554 & $* *$ & 28 & 0.433 & $* *$ & & & \\
\hline & $* 519 n f i c a n c e$ & & \\
\hline 10.05$)$ & & & & & \\
\hline
\end{tabular}

*Significance at $(0.05)$ level

** Significance at (0.01) level

Through the table above it is set that all paragraphs of the achievement test used to measure the impact of active learning at the achievement of sixth primary grade female students in Geometry is a statistically significance, which confirms its internal consistency with the total grade of the test it belongs to.

Achievement test reliability: to confirm the reliability of the achievement test, the researcher applied this test on an exploratory sample consists of (42) student from out side the study sample. Next he used the following methods:

- semi retail method: the researcher had calculated the correlation coefficient between the results of even and individual paragraphs. He found that correlation coefficient before modifying is (0.902) and the correlation coefficient after modifying is (0.949). The thing that indicates that test has a high level of reliability which can assure the researcher to apply it on the study sample.

Reliability through re-implementation: the researcher applied the achievement test on an exploratory sample consists of (42) female students from outside the study sample. Three weeks later, he re-applied the test on the same sample to find that the reliability factor is $(0.812)$, which considers statistically significant and high reliability factor. Thus, the researcher was able to confirm the accuracy and reliability of the achievement test. So he test be formed in its final for and valid for implementation on the primary study sample.

Final form of the achievement test: in the light of what have stated, the achievement test was prepared in its final form of two questions: the first question contains (34) multiple choice paragraphs, the second question contains (6) arithmetic paragraphs. 
Fifth $\backslash$ The equivalence of two study groups: the equivalence of the two study groups experimental and control, was confirmed regarding to: ( pre Mathematical skills' test, the students' grades in Mathematics, achievement in all study subject, and chronological age)

The following table (4-3) explains it

\begin{tabular}{|c|c|c|c|c|c|c|}
\hline Variable & Group & $\begin{array}{l}\mathrm{Nu} \\
\mathrm{mbe} \\
\mathrm{r}\end{array}$ & $\begin{array}{l}\text { Mea } \\
n\end{array}$ & $\begin{array}{l}\text { St. } \\
\text { D }\end{array}$ & $\begin{array}{l}\mathrm{T}- \\
\text { val } \\
\text { ue }\end{array}$ & $\begin{array}{l}\text { Sig.lev } \\
\text { el }\end{array}$ \\
\hline \multirow[t]{2}{*}{ Pre-test } & Control & 47 & 5.81 & $\begin{array}{l}3.8 \\
6\end{array}$ & \multirow{2}{*}{$\begin{array}{l}- \\
1.6 \\
6\end{array}$} & \multirow{2}{*}{$\begin{array}{l}\text { Not } \\
\text { signific } \\
\text { ant }\end{array}$} \\
\hline & $\begin{array}{l}\text { Experime } \\
\text { ntal }\end{array}$ & 46 & 7.13 & $\begin{array}{l}3.8 \\
0\end{array}$ & & \\
\hline \multirow{2}{*}{$\begin{array}{l}\text { Students' } \\
\text { score at } \\
\text { mathemat } \\
\text { ics }\end{array}$} & Control & 47 & $\begin{array}{l}37.5 \\
5\end{array}$ & $\begin{array}{l}9.4 \\
8\end{array}$ & \multirow[t]{2}{*}{$\begin{array}{l}0.1 \\
8\end{array}$} & \multirow{2}{*}{$\begin{array}{l}\text { Not } \\
\text { signific } \\
\text { ant }\end{array}$} \\
\hline & $\begin{array}{l}\text { Experime } \\
\text { ntal }\end{array}$ & 46 & $\begin{array}{l}37.2 \\
1\end{array}$ & $\begin{array}{l}9.0 \\
0\end{array}$ & & \\
\hline \multirow{2}{*}{$\begin{array}{l}\text { Students' } \\
\text { score at } \\
\text { all } \\
\text { subjects }\end{array}$} & Control & 47 & $\begin{array}{l}312 . \\
98\end{array}$ & $\begin{array}{l}53 . \\
52\end{array}$ & \multirow[t]{2}{*}{$\begin{array}{l}0.6 \\
3\end{array}$} & \multirow{2}{*}{$\begin{array}{l}\text { Not } \\
\text { signific } \\
\text { ant }\end{array}$} \\
\hline & $\begin{array}{l}\text { Experime } \\
\text { ntal }\end{array}$ & 46 & $\begin{array}{l}304 . \\
93\end{array}$ & $\begin{array}{l}68 . \\
74\end{array}$ & & \\
\hline \multirow[t]{2}{*}{$\begin{array}{l}\text { Chronolo } \\
\text { gical age }\end{array}$} & Control & 47 & $\begin{array}{l}11.5 \\
9\end{array}$ & $\begin{array}{l}0.1 \\
8\end{array}$ & \multirow{2}{*}{$\begin{array}{l}- \\
1.0 \\
1\end{array}$} & \multirow{2}{*}{$\begin{array}{l}\text { Not } \\
\text { signific } \\
\text { ant }\end{array}$} \\
\hline & $\begin{array}{l}\text { Experime } \\
\text { ntal }\end{array}$ & 46 & $\begin{array}{l}11.6 \\
3\end{array}$ & $\begin{array}{l}0.1 \\
9\end{array}$ & & \\
\hline
\end{tabular}

The statistically significant limitations starts at SMA $(\alpha=0.05)$ and free degrees (91) at tabular value (2.00).

The statistically significant limitations starts at $\operatorname{SMA}(\alpha=0.01)$ and free degrees (91) at tabular value (2.66).

The table above clarifies that the value of counted "T" equals $(1.66,0.18,0.63,0.01)$ respectively and it is smaller than the tabular value of "T" which equals (2.00) at free degree (61) and SMA $(\alpha=0.05)$, which indicates that there is no a statistically significance differences between the experimental and the control groups, which means that the two groups are equivalent..

Sixth Steps of the study: the present study included the following steps:

1. Viewing the educational literature related to the current study in order to identify the manner of preparing study tools.

2. Preparing an achievement test to measure the achievement of the sixth primary grade female students' in Geometry.

3. Applying the test on a small sample in order to identify the time of the test and to discover the ease and difficulty, the coefficient of discrimination and to investigate the accuracy and decision of the test.

4. Choosing two simple random divisions from among all divisions in Nusirat (F) elementary school, where one group was chosen as an experimental group and the other one as a control group.
5. Confirming the equivalency of the two study groups, control and experimental, variables that are expected to affect the dependant variable which is the achievement of the sixth primary grade female students in Geometry according to: ( pre achievement test, chronological age).

6. Applying the test before executing the experiment (pre test) on the members of the study sample in order to confirm of the equivalency of the two study samples and to study the impact of using active learning.

7. Teaching the study unit to the two control and experimental groups according to the experimental design, accordingly the experimental group learn by using active learning and the control group learn using the traditional way. The experimental design. That was on Tuesday, 7th of February, 2012 of the academic year 2011/2012.

8. teaching by using active learning was ongoing until the end of Thursday 15/3/2012 of the same year, six classes a week. i.e. the implementation of the experiment takes about (30) classes a week, (45) minutes for each class, and that agrees with the allocated time for teaching the fifth unit entitled by (Geometry and measurement) of the Mathematic text book for the sixth primary grade female students. Taking into considerations the following points:

- The two groups were taught at the same period of time.

- The allocated time for both lectures was the same.

- $\quad$ The students who failed the course before were excluded.

9. At the end of implementation of the experiment, the test was re-applied to dictate the impact of using active learning at the achievement of the sixth primary grade female students in Geometry.

10. Correcting tests, grading, collecting data, analyzing the results of the study and discussing it.

11. Identifying recommendations of the study in the light of the previous studies, then presenting a set of recommendations.

\section{Seventh/Statistical methods in use:}

The Statistical Package for the Social Science (SPSS) had been used to execute analysis and statistics required for the data of the test. As the election of (T) (T-test) for two independent samples to study the differentials among variables, in addition to calculating the magnitude of the active learning's impact through calculating Eta square $(\eta 2)$

\section{DISCUSSING AND EXPLAINING THE RESULTS OF STUDY}

The following results were obtained according to the study's questions and assumptions, and it was as bellow: 


\subsection{Presenting the results of the first question}

The first question articulates the following: dose the level of the sixth primary grade students' achievements in the two groups (experimental and control) differs in the case of using different teaching techniques (active/ traditional learning?).

To answer this question the first assumption of the study was formulated, and which articulate the following: (there are no statistical significant differentials at the significant level $(\alpha \leq 0.05)$ between the average of the sixth primary grade female student in geometry in the experimental group, and the average of the control group in the post achievement test; and to examine this assumption, a "T" test was used for two independent samples, and the results was as viewed in table "5-1"

Table "5-1" present the "T" test result to compare between the grades average of the sixth primary grade female students in the control group, and the average of the sixth primary grade in the experimental group at the post test.

\begin{tabular}{|l|l|l|l|l|l|}
\hline Group & $\begin{array}{l}\text { No. Of } \\
\text { students }\end{array}$ & SMA & STD & $\begin{array}{l}\text { T } \\
\text { valu } \\
\text { e }\end{array}$ & Sig \\
\hline Control & 47 & 22.83 & 3.82 & $\begin{array}{l}- \\
19.9\end{array}$ & 0.01 \\
\hline $\begin{array}{l}\text { Experiment } \\
\text { al }\end{array}$ & 46 & 36.33 & 2.58 & 2 & \\
\hline
\end{tabular}

The limits of statistical function are at the SMA $(\alpha=0.05)$ and free degrees (91) at tabular value (2.00).

The limits of statistical function are at the SMA $(\alpha=0.01)$ and free degrees (91) at tabular value (2.66).

The above table illustrates the value of counted "T" equal (19.92), and its larger than the value of tabular "T" which equals (2.66) at free degree (91) and statistically significant level $(\alpha=0.01)$.

This indicates statistically significant differentials between the six primary grade SMA at the experimental group in the results of the post achievement test; in favor of the sixth primary grade students' SMA at the experimental group of the post achievement test.

About the magnitude of the impact of using active learning on the sixth primary grade student' achievements in geometry.

Eta square N2 was counted to confirm that the magnitude of differences resulted in using "T" test are real and refer to the variables of the study not to coincidence, the next table explains what has been discussed:

Table (5-2) view the effect's magnitude of the "T" test to the differentials among the students in the two experimental, control groups

\begin{tabular}{|c|l|l|l|l|l|l|}
\hline Test & $\begin{array}{l}\text { No } \\
\cdot\end{array}$ & SMA & t-test & $\begin{array}{l}\text { Eta } \\
\text { value }\end{array}$ & $\begin{array}{l}\text { D } \\
\text { value }\end{array}$ & effect \\
\hline Control & 47 & 22.83 & & 0.81 & 4.17 & $\begin{array}{l}\text { LAR } \\
\text { GE }\end{array}$ \\
\cline { 1 - 3 } Experi \\
mental & 46 & 36.33 & -19.92 & & & \\
\hline
\end{tabular}

The table above clarifies that Eta square equals (0.81) which indicates a large magnitude of impact.

(Afanah, 2000) pointed out that the effect's magnitude considers large if the value of Eta square is larger or equal (0.14), i.e. the magnitude of effect considers a complementary phase for the statistical function and do not replace it.

All the studies previously presented agrees these results. The superiority of development in using active learning at the achievement of the sixth primary grade students in geometry upon the traditional method can be attributed, though they represent the same content, to the following reason:

1. Using active learning raises competition between the students which contribute effectively in attracting students and raising the level of ambitious and simulate there continues desire through achieving other activists; which had a clear effect on increasing their achievement, on the other hand, the student in the control group abilities was not simulated through the regular teaching method as the same as the active learning method.

2. The flexibility of the active learning that contains a group of effective means, tools and educational activities in an interesting content, all of these elements Concerted together to achieve the desired

3. Active learning depends on the students' activity as he's the core of educational process, and eliminate the students' boredom during the educational situation.

4. Active learning assists increasing the students' visual attention, as it provides them with continues motivation regarding the entertainment that active learning provides.

5. Active learning provides a cheerful environment in the class, and attain the students with new interesting experiences through participating in active learning.

Those results agrees with many studies had reached e.g. Mada'h (2009), Asser'S study (2001), Suliman'S study (2004),Abu elhameed'S study (2004), Al toudry'S study (2003), Fox's study (2008),Davaid \&Wilder, (2003), Coy's study (2001).

\subsection{Viewing the results of the second question with discussion}

The second question articulated the following (dose the achievement's level of the sixth primary grade in geometry differs achievement's rises levels in the two experimental, control groups according to the teaching method (active/traditional)?

To answer this question the second assumption was formulated which articulates the following: there are no statistically significant differentials at the significance level $(\alpha \leq 0.05)$ between the high achievement student's SMA in the sixth primary grade at geometry in both experimental and control groups at the post achieving test. To confirm this assumption validity, the variances significance among the medium post achieving female students in experimental group and the control, high achievement, group had to be extracted, by using the $(\mathrm{U})$ and $(\mathrm{Z})$ tests as it explained in table (5-3) 
Table (5-3): the two high achieving students SMA in the two experimental and control groups at posttest and the values of $(U)(Z)$.

\begin{tabular}{|l|l|l|l|l|l|l|}
\hline $\begin{array}{l}\text { High } \\
\text { achiev } \\
\text { ement }\end{array}$ & $\begin{array}{l}\text { N } \\
\text { o. }\end{array}$ & $\begin{array}{l}\text { Rank } \\
\text { Averag } \\
\text { e }\end{array}$ & $\begin{array}{l}\text { Rank } \\
\text { sum }\end{array}$ & $\begin{array}{l}\text { U } \\
\text { value }\end{array}$ & $\begin{array}{l}\text { Z } \\
\text { value }\end{array}$ & Sig. \\
\hline $\begin{array}{l}\text { Contro } \\
\text { l }\end{array}$ & 15 & 8 & 120 & -- & -4.73 & 0.01 \\
\cline { 1 - 3 } $\begin{array}{l}\text { Experi } \\
\text { mental }\end{array}$ & 15 & 23 & 345 & & & \\
\hline
\end{tabular}

Z" tabular value at Significance level (0.01) equal (2.58)"

The table above illustrates that the rank's average for the experimental group equals (23), the rank's average for the control group equal (8) i.e. the experimental group rank's average is larger than the control's group.

As evidenced through Man-Whitney test that the counted value of $(Z)$ (4.73), while $(Z)$ tabular value (2.58), at significance level (0.01). Thus it becomes Statistical function at significance level $(0.01)$, because the $(\mathrm{Z})$ counted value is larger than $(\mathrm{Z})$ tabular value. Therefore we reject the zero assumption and accept the alternative assumption, i.e. there are Statistically significance differentials at (0.01) significant level between the grades' average of the high achievement female students of the sixth primary grade in experimental group at post test, in favor of the high achievement students average at the experimental group in post test, and this result attributed to the following:

1. Using the active learning method increases the low achieving students attainment in Geometry.

2. The effectiveness of active learning in rising high achievement students, as it seeks to create a democratic environment and comfortable atmosphere inside the class room. it also presents the information in an environment that is closer to that of what students prefer.

3. Active learning method empowered the high achieving students with the manner of having a serious and purposeful discussions and the shared debates among students the thing that lead to establishing their perception of information and the development of their thinking process which consequently lead to increasing their achievement.

4. The information the students received in there well mentally status were more reliability than the information they received while they are confused or afraid of punishment. Therefore, and for other reasons, active learning simulate the cheerful and encouraging environment .

5. active learning method encourages the high achieving students to work with each others, the thing that makes the contacting process among them easier, so the information become easier to understand and deeper in meaning.

\subsection{Viewing the results of the third question with discussion}

The third question's articulated the following: (Does the achievement level of the six primary grade low achievement female students in Geometry changes the achievement falls in the two groups (control and experimental) according to the method of teaching (traditional /active learning)?

To answer this question, a third assumption had to be formulated, which articulates that: (There are no statistically significance differentials at the significance level $(\alpha \leq 0.05)$ between the grade's average of the achievement falls of the sixth primary grade in Geometry and the grade's average of the low achievement female students in the control group at the post achievement test. To investigate the accuracy of this assumption the differentials significance of the achievement average between the students of experimental group and the low achievement control group had to be extracted (U) and (Z) tests as it explained in table (8).

Table(5-4): the grades' average of the achievement falls for both experimental and control groups in the post test which value is $(\mathrm{U})$ and $(\mathrm{Z})$

\begin{tabular}{|l|l|l|l|l|l|l|}
\hline $\begin{array}{l}\text { High } \\
\text { achiev } \\
\text { ement/ } \\
\text { Fall }\end{array}$ & $\begin{array}{l}\text { N } \\
\text { o. }\end{array}$ & $\begin{array}{l}\text { Rank } \\
\text { Avera } \\
\text { ge }\end{array}$ & $\begin{array}{l}\text { Ran } \\
\text { k } \\
\text { sum }\end{array}$ & $\begin{array}{l}\text { U } \\
\text { valu } \\
\text { e }\end{array}$ & $\begin{array}{l}\text { Z } \\
\text { valu } \\
\text { e }\end{array}$ & Sig. \\
\hline $\begin{array}{l}\text { Contro } \\
\text { l }\end{array}$ & 15 & 8 & 120 & -- & -4.77 & 0.01 \\
\cline { 1 - 3 } $\begin{array}{l}\text { Experi } \\
\text { mental }\end{array}$ & 15 & 23 & 345 & & & \\
\hline
\end{tabular}

(Z) tabular value at the significance is (0.01) equals (2.58)

The table above clarifies that the ranks' average for the experimental group is (23), but that the ranks' average for the control group is (8), i.e. the rank's experimental group average is larger the rank's control group average.

At the same issue Man-Whitney's test illustrates that $(Z)$ counted value is (4.77), while the $(\mathrm{Z})$ tabular value is (2.58), at significance level (0.01). Thus it becomes a statistically significance at the significance level $(0.01)$, because $(Z)$ counted value is larger than $(\mathrm{Z})$ tabular value. Therefore we reject the zero assumption and accept the alternative i.e. there are statistically significance differentials at level $(0.10)$ between the grades' average of low achievement students in the sixth primary grade at the control group, and grades' average of the low achievement in the same grade at the experimental group in favor of the grades' average of the low achievement students at the experimental group in the post achievement test. Such result is owed to the following:

1. Using the active learning method increases the low achievement students attainment in Geometry.

2. active learning takes into consideration the individual differences among students the of the same class, as students' intelligence, abilities, and moods are varies. Active learning faces the individual differences, it gives the opportunity for both; the high IQ student to innovate in the learning process and the average student to participate in the lesson in a practical granular way.

3. Using active learning allowed the students to express themselves with no fear, but with ease perception and explanation of the subject it also increases the students' self-esteem and earns them a greater love for their teachers the thing that was vacant in their colleagues with the traditional method. 
4. Using active learning impacts at rising the achievement level of the low achievement students due to its positive role which figuratively based on a student in the learning process who doesn't just receive the information, but even makes him better prepared to participate in the learning situations and also tries to empower student with other experiences closer to the scientific reality and increases the learner's motivation towards education.

\section{Recommendations:}

In the light of the results of the present study, came out the following recommendations:

- Training the teachers of Mathematics on the various strategies of active learning for its positive impact of attaining them with the different teaching skills.

- Identifying the modern strategies for active learning, and empowering Mathematical teachers with it and connecting it with their teaching environment, in order to achieve the impact in their practical life.

- Encouraging teachers on creativity in teaching and adopting modern strategies such as active learning and the different techniques it includes (cooperative learning and brain storming, problem solving) and to leave the traditional methods that totally neglects the role of learner in education process and makes him just a receiver for information.

- Providing a class environment that contributes in the students' interacting and involving them all in the activities that increases their achievement and develop their skill of critical thinking

- Focusing upon the organization of the educational environment of Mathematic classes where the learning is being done in an

\section{ACKNOWLEDGMENTS}

Best thanks to the IJCA who permitted to us to publish our paper.

\section{REFERENCES}

[1] Abdul Karim, G. 2009. "The impact of a program based on active learning in social studies for the development of some life skills and achievement among students with mental disabilities who are able to learning", unpublished Master Thesis, Faculty of Education, Qena, South Valley University.

[2] Abu-El Hamd, Z. 2004. "The effectiveness of the use of active learning strategies in the achievement of fourth grade students in mathematics and their inclination towards the study", unpublished Master Thesis, Minia University: College of Education.

[3] Afanah, I. 2000. Effect size and its uses in the detection of the credibility of educational and psychological research results, Journal of Educational Research and Studies. Palestinian Society for Research and Educational Studies Palestinian ( 3). atmosphere of excitement and entertainment, through formulating an effective Mathematical problems that touches the students reality and contributes in improving the students

- achievement and their trends towards Mathematics.

- Designing Mathematical books according to active learning strategies and the modern learning/teaching Method.

- $\quad$ Publishing educational publications in all fields of study to tell them about active learning, the ways of applying it, it's advantageous, and the role of both learner and teacher.

- Designing an active learning website, where it presents active learning strategies with detailed explanation for each strategy: what is it about, examples for each strategy, the way of implying the strategy in the different education level.

\section{Suggestions of the study:}

After the discussion of the study results and identifying a group of recommendations, the study offers a group of suggestions, as the following:

1. Executing similar researches to study the impact of active learning in the other branches of Mathematics.

2. Studying the use of active learning in the development of thinking process in all education levels.

3. Studying the use of active learning in the development of student's trends towards Mathematics

4. Executing a study to identify teachers' ability to use active learning in teaching.

[4] Al-Astal, M. 2010. "The impact of the application of active learning strategies in the achievement of ninthgrade students in history and the development of critical thinking", unpublished Master thesis Middle East University for Graduate Studies, Faculty of Educational Sciences.

[5] Al-legany, Ahmed and Ali, Jamal 2003. Glossary of knowledge in educational curricula and teaching methods, Cairo: world of books.

[6] Al-Maliki, A. 2009. "The effectiveness of the proposed training program to give teachers some math skills and active learning on their students' achievement and attitudes towards mathematics," unpublished Ph.D. thesis, Faculty of Education, University of Umm AlQura.

[7] Al-tuodry, A. 2003. "A proposed strategy for teaching third-grade mathematics and its impact on mathematical thinking and the translation exercises for verbal learning and retention", Journal of the Faculty of Education, 19, 2, Assiut University: College of Education

[8] Assr, R. 2001. "The effectiveness of active learningbased materials in the teaching manual algebraic 
equations", Journal of Mathematics, the Egyptian Society for Mathematics, vol. (4), Zagazig University: College of Education.

[9] Bedeer, K. 2008. Active learning, first edition, Amman: Dar al-masirah for publication, distribution, and printing

[10] Coy,(2001):"teaching fifth grade mathematical concepts:effects of word problems used with traditional methods",the Eric datadase No452054.

[11] David, D. and Wilder, S.2003. Learning by Doing In: David D. el al., Learning to Teach Math in Secondary School, London ,Rutledge, Available at: http:// www. National review. com/kopell 21900.shtml .

[12] Fox, L., 1998:"The of Graphing Calculator Used in an Active Learning Environment on Intermediate Algebra Students Achievement and Attitude" . AAT9827825.

[13] Maddah, S. 2009. "The impact of the use of active learning in the achievement of some of the engineering concepts and the trend towards mathematics at the fifth grade of primary school girls in Makkah city,1,1Muharam (1430)/Jan.2009 .

[14] Mathews . lisakey 2006 . Elements of active learning " Available at :http :/www2. una.edu / geography /active / el ements. Htm.
[15] Poppenhagen ， B.W. 2005 " Active Learning for Postsecondary Education: Study of Tow Learning Designs ", Paper Presented at the annual meeting of the American Educational Research Association , Los Angeles CA, ED20127, April 13-17).

[16] Saada, JA and et al .2006. Active learning between theory and practice, Oman, Sunrise House.

[17] Shepardson,D.P. 1996. Social Interaction and Learning In Small Group" , International Journal of Education, vol.13,pp.21-29.

[18] Suliman, R. 2004. "The effectiveness of active learning in the teaching of statistics for students in middle school achievement and the development of a statistical sense they have," the Fourth Scientific Conference: Mathematics of general education in the society knowledge , Benha Faculty of Education, University of Zagazig, (7-8) in July

[19] Zaidi, F. 2008. "The impact of active learning in the development of innovative thinking and academic achievement in science in the third grade students in public schools average in Makka City, Unpublished MA Thesis, College of Education, University of Umm AlQura. 